\title{
Catholic education and a new Christian humanism
}

\author{
In honour of Grace
}

\section{Caroline Healy}

\section{Introduction}

Gerald Grace has throughout his body of work examined the interface of Catholic virtues and the challenges to them with ever-shifting contemporary educational policy developments. ${ }^{1}$ He has remained an unwavering advocate of these perennial virtues in Catholic education, which can be located broadly under the concept of Christian humanism and include the preferential option for the poor (education for all); contributing to the common good; the importance of solidarity and community around the education mission and academic education as a means, not an end. Last, he considers the formation of the whole person as vital work of Catholic schools and the essentialness of the role of school leaders and teachers in this regard, who lead by example living virtuous lives, reflecting a sacramental vision articulated in this chapter. ${ }^{2}$

\section{Educating to fraternal humanism ${ }^{3}$}

In the view of the Congregation for Catholic Education (CCE), the following is required to:

...humanise education, that is, to make it a process in which each person can develop his or her own deep-rooted attitudes and vocation, and thus contribute to his or her vocation within the community. 'Humanising education' means putting the person at the centre of education, in a framework of relationships that make up a living community, which is interdependent and bound to a common destiny. This is fraternal humanism.

(CCE, 2017, para. 8)

In describing current scenarios, the document echoes Pope Paul VI's 1967 Encyclical Populorum Progressio, which at the outset stated that:

The contemporary world, multifaceted and ever changing, is hit by multiple crises of different kind: economic, financial, labour; political crises

DOI: $10.4324 / 9781003171553-11$ 
including within participatory democracy; environmental and natural crises; demographic and migratory crises...

(CCE, 2017, para. 3)

In the section on Humanising Education, the significance of the role of the teacher is alluded to:

A humanised education, therefore, does not just provide an educational service, but deals with its results in the overall context of the personal, moral and social abilities of those who participate in the educational process. It does not simply ask the teacher to teach and students to learn [emphasis is my own], but urges everyone to live, study and act in accordance with the reasons of fraternal humanism.

(CCE, 2017, par. 10)

The highlighted words reflect John Sullivan's (2001, pp. 134-135) concept of 'reciprocity and mutuality' and 'charismatic circularity', the term used by the Congregation for Catholic Education in its Consecrated Persons and Their Mission in Schools (2002), in the context of the transmission of distinctive charisms. In essence, this perspective claims that learning is a two-way process and the teacher is enriched to the extent to which he/she is open to the possibility of learning from recipients, in this case students. Parker J. Palmer (1998) also places a good deal on emphasis on the appropriateness of the 'space' in which the vocation of the teacher is nourished. Resonating with Sullivan's (2000, p. 185ff) concept that schools should primarily be 'hospitable spaces for learning', Palmer articulates the nature of the space in a series of paradoxes, for example bounded yet open, welcoming yet challenging and inviting both the voice of the individual and the group.

\section{Humanism: Historical context}

Franchi (2014) makes the point that no contemporary reference to humanism can omit reference to the historical notions of humanism exemplified in the work of Francesco Petrarcha (1307-1374) and Desiderius Erasmus (1466-1536). Bowen (1975, p. 337) makes the point that, in essence, these Renaissance humanists were inspired by classical antiquity, access to which emerged from the time of St Thomas Aquinas (1227-1274) onwards. In what amounted to a return to the sources of the Hebrew and Greek scriptures alongside key philosophical texts such as those of Plato and Aristotle from the 4th century BC, these scholars focused on an orientation towards the Good, encompassing a positive attitude towards the human as opposed to a perspective of the human blocked by the twin barriers of frustration and sin: 'freedom of the will' as opposed to 'bondage of the will' in the classical binary of Erasmus and Luther.

In his book, The Crisis of Western Education, Christopher Dawson speaks of the 'age of humanism' as: 
...inspired by an intense devotion to classical culture but not conscious of any disloyalty to the Christian tradition. The great humanist educators... were themselves devout Christians who wished to unite the intellectual and aesthetic culture of Hellenism with the spiritual ideals of Christianity.

(1961, p. 31)

This unity between classical culture and Christian tradition is exemplified in the work of Aquinas, particularly in the context of Natural Law and conscience, which will be referenced subsequently. Since the early 1980s, there has been renewed scholarly interest in the concept of Christian humanism. A number of official Catholic documents have stressed the importance of 'Christian humanism', as a vehicle of Christian social teaching and, indeed, as a key principle of Catholic education with a holistic approach to education. This can be regarded as an architectonic concept. ${ }^{4}$ In Re-Envisioning Christian Humanism (2016), Jans Zimmermann endeavours to recover a Christian humanist ethos in our contemporary context. In a related work, Zimmermann (2012) argues for an incarnational humanism built around the person of Christ in his uniting in His own person the divine and the human. Zimmerman's work encapsulates the view that any version of Christian humanism must include an openness to the transcendent as one of its constituent features and an anthropology that is deeply influenced by Christology.

In an ecclesiastical context, Pope Benedict XVI's 2007 address to the first European Meeting of University Lecturers in Rome is particularly germane. Reflecting the dialogue between classical culture and Christian tradition alluded to earlier, he suggests that:

Historically, it was in Europe that humanism developed, thanks to the fruitful interplay between the various cultures of her peoples and the Christian faith. Europe today needs to preserve and re-appropriate her authentic tradition if she is to remain faithful to her vocation as the cradle of humanism.

(2007, p. 1)

Rooting his presentation in the centrality of the person of Christ, Pope Benedict goes on to voice his conviction that 'unless we do know God in and with Christ, all of reality becomes an indecipherable enigma' (2007, p. 1). It is worthy of note in this context that fruitful dialogue requires a clear understanding of one's own philosophical, cultural and theological traditions and a commitment to present this worldview to a variety of audiences. The sacramental perspective, in framing all Christian ministry around the person of Jesus, reflects Pope Benedict's conviction.

\section{The sacramental perspective}

The idea of Christ as a primordial sacrament first became popular with the work of Otto Semmelroth, a German Jesuit who, in 1953, published The Church as the Original Sacrament. It was Karl Rahner's writings, together with 
those of Edward Schillebeeckx, that brought the idea of Christ as the primordial sacrament and the Church as a basic sacrament into international prominence. In 1961, Rahner published The Church as Sacrament while Schillebeeckx had published Christ, the Sacrament of the Encounter with God in 1964. In these writings, the idea of the Church as a basic sacrament and Jesus in his humanity as a fundamental or primordial sacrament are seen to be critically interdependent.

\section{The sacramental perspective in an educative perspective}

According to Lydon (2011, p. 80ff), in the context of the Catholic school the sacramental perspective is a dominant paradigm within the theological framework of the Second Vatican Council. By engaging in the ministry of teaching, the individual Christian is responding to his or her primary call to be a disciple of Jesus in a distinctive manner, reflecting the notion of charisms being a concrete realisation of the universal gift of God through Christ to all the baptised explored earlier. This fundamental calling demands that all teachers model their ministry on that of Christ. Teachers are, in effect, signs of the presence of Christ within their educational community. As Parker J. Palmer (1998, p. 2) puts it, they 'teach who they are'. The notion that the Christian educational vision is 'passed on in the very lives of the teachers themselves', in the view of Grassi (1973), constitutes a key theme in many post-Vatican II documents.

\section{The sacramental perspective and dialogue}

Earlier in this chapter, I hinted towards a dialogue, principally in the context of the relationship between student and teacher, seminal in the context of a holistic perspective. In terms of the sacramental perspective, in his article 'Faith and the Catholic Teacher' (2012), Lydon uses the term 'witness' sixteen times in support of his argument that the whole tone of post-Vatican documents published by the Congregation for Catholic Education is dominated by the theological idea that Christ is the foundation of all educational enterprises and that commitment to modelling their lives on Christ is the only effective way in which teachers can translate this vision into practice.

By modelling her ministry on Christ, the teacher will reflect the key aspects of that ministry which encompass many qualities: an invitational and inclusive approach to all, effective presence, respect for an individual's discernment and challenge, reflected in the response of the first disciples. Each of these aspects is underpinned by a commitment to the building of community, which is a central feature of the sacramental perspective, both being linked integrally in all post-Vatican II documents on Catholic education.

Christians and the followers of other religions can work together via interreligious dialogue to address issues of social responsibility that they have in common to create a new humanistic ethos. The Second Vatican Council presented 
a ground-breaking document, Nostra Aetate (the Declaration on the Relation of the Church to Non-Christian Religions), on the relationship between the Catholic Church and other religions.

The Church, therefore, exhorts her sons, that through dialogue and collaboration with the followers of other religions, carried out with prudence and love and in witness to the Christian faith and life, they recognize, preserve and promote the good things, spiritual and moral, as well as the socio-cultural values found among these men.

(Nostra Aetate, 1965, par. 2)

Meeting God in Friend and Stranger is the 2010 teaching document on interreligious dialogue from the Catholic Bishops' Conference of England and Wales. It reminds Catholics that they are called by their baptism to engage in dialogue with others, and specifically with people of other religions. This is part of the Church's task of continuing the dialogue that God engages with His Church, and of reading the signs of His will in our times. The document stresses that this dialogue is not restricted to academics, but takes place where everyday life is shared in an atmosphere of respect and openness. Shared experiences of worship - where the worship takes the form not of coming to pray together, but of coming together to pray, is also a valuable aspect of dialogue, and one which meets appropriately the desire to share occasions of grief, joy and remembrance (see also Whittle, 2018). The document recognises also that most young people will not enter into interreligious dialogue in a formal academic or theological context. Christians are, however, called to live interreligious dialogue in practice by building community with people of other faiths and belief-systems. Catholic schools are challenged 'to prepare for that lifetime of interreligious dialogue' (Catholic Bishops' Conference of England and Wales, 2010 , p. 85). This latter statement resonates with the mutual respect, and tolerance, of those with different faiths and beliefs spoken of in discussions around the concept of British Values.

\section{Christian humanism: A return to the virtues}

In the context of advocacy for people across the world described by Pope Francis as being 'on the peripheries', Catholic-inspired organisations were called to 'move toward a more inclusive society' (2017) and later to position themselves as 'Promoters of Humanity' (Pope Francis, 2019). ${ }^{5}$ Yet, perhaps few when asked would be able to define the term 'humanism', even recognised experts. This signifies an inherent challenge of reducing the term 'Christian humanism' to a slogan, analogous to the overuse of the term 'Gospel values'.

Gospel Values is a term used often but only makes sense within the matrix from which it emerges. According to Lydon (2011), virtue is a stronger term than values. He holds the view that virtues dwell in us whereas values, possibly, 
are more peripheral, analogous to the contrast between ethos and culture. Virtues involve training, apprenticeship, community, communication, self-subordination, disposition, happiness, building on Thomas Aquinas' treatise on virtue, whereas the term 'value' tends to be contingent and in danger of becoming particularly subjective. Gertrude Himmelfarb in The De-Moralisation of Society (1995) distinguishes between virtue and values, possibly over-emphasising the dichotomy. She claims that Victorian virtues/values were very strong then, highlighting the strength of the family in transmitting virtues. However, she maintains this strength has been eroded by a greater emphasis on economics and a utilitarian approach:

...in this scientific century, morality, virtue and character gradually but steadily became verbal artefacts of an age of religion and superstition. Values brought with it the assumptions that all moral ideas and rules are subjective and relative, and in effect, that all human behaviour is socially, economically or genetically determined.

(1995, p. 138)

Scholars such as Boland (2007) argue for a return to the virtues, significant in the context of the classical and medieval roots of humanism, referred to above. Perhaps the most extensive treatment of the concept of virtue, built upon by successive generations of scholars, is contained in Aquinas' Summa Theologica, written in 1265-1274 and originally published in 1485 .

In articulating the virtue of prudence, Aquinas refers to the Aristotelian concept of phronesis, 'practical wisdom', which, again, is particularly relevant to the notion of character or disposition. Terence McLaughlin (1999) invokes the idea of phronesis when exploring the concept of 'the reflective practitioner' and argues that the development or formation of character is central to such a concept. This is a different emphasis for reflection, putting the focus on professional competencies. McLaughlin describes phronesis as 'a major orderingagency in our lives generally' (1999, p. 120).

The significance of tradition and community is, undoubtedly, an integral prerequisite to growth in virtue, in the mind of Aquinas. Moral development is always within communities and traditions whose narratives teach the virtues and so provide a model of character that is worthy of emulation and resonating. According to Lydon (2011), this chimes with a key theme from the Pauline corpus in the NT.

\section{A new humanism that is timely in our contemporary global context}

The term 'anchorless deliberator' is particularly pertinent in the context of the call for 'a new Christian humanism'. Following Frankfurt (1971), Charles Taylor (1985) draws a distinction between weak evaluation and strong 
evaluation. Frankfurt distinguishes between two kinds of desires. We experience first-order desires such as hunger along with other animals. However, secondorder desires, in which we evaluate other desires - I am hungry but should watch my diet - are unique to human beings. Taylor (1985) elaborates with a distinction between two sorts of second-order, evaluative desires. Weak evaluation entails desires about matters based on mere feeling. Strong evaluation, in contrast, entails desires that define the very person you choose to be. To choices concerning desires of this sort, Taylor argues, entail values that originate outside of yourself, in community, tradition, nature, or God. In other words, to exercise what Taylor calls human agency a person needs strong values, and these can surely be drawn under the appropriate circumstances from faith traditions.

Terence McLaughlin (1985), building on Taylor's distinction, speaks of autonomy via faith. In his view, an upbringing in a living (or what he calls a thick) tradition can lead to a strong sense of personal autonomy. When this is accompanied by a good understanding that comes from maturity, young people should take increasing control of their own lives. Religious traditions can in this way be regarded as a source, not a hindrance to, of moral independence. This is because the values one learns through religious instruction could become the basis upon which one makes independent choices.

To say that autonomy can be achieved or enhanced via faith presupposes an individual who is embedded in tradition, history, culture and language. Secularism or comprehensive liberalism is not neutral, in this view, but constitutes a tradition (or more precisely, a variety of traditions) in its own right into which a child may be initiated. To be sure, people raised in different ethical and religious traditions may share many things in common, including almost certainly some common rational grounds for shared discourse and disputation. However, these rational capacities are shaped and moulded by tradition, culture, history and language as a child matures. McLaughlin's position resonates with that of Bryk et al.'s (1993) concept of 'openness with roots' that emerged from their empirical research concerning the impact of Vatican II on Catholic secondary education in the US. It involves thus maintaining a balance between some form of critical intelligence and serious religious commitment. This is reflected in the whole tenor of Vatican II, which sought to offer, rather than impose, a distinctive Catholic education project.

This chapter concludes by returning to the Congregation for Catholic Education's document:

It [fraternal humanism] does not aim to create division and divergence, but rather offers places for meeting and discussion to create valid educational projects. It is an education - at the same time - that is sound and open, that pulls down the walls of exclusivity, promoting the richness and diversity of individual talents and extending the classroom to embrace every corner of social experience in which education can generate solidarity, sharing and communion. 
This sums up most effectively what Grace's work has aimed to achieve ${ }^{6}$.

I wish to acknowledge, with much gratitude, my colleague John Lydon, in the preparation of this chapter.

\section{Notes}

1 Relevant examples would be Grace (2002), Grace (2007), Grace (2010), Grace (2013) and Grace (2016).

2 A tradition of Catholic theology which proved itself particularly amenable to the Christian mindset.

3 John Sullivan's work has a series of references to 'reception' within Catholicism, in what is, essentially, a critique of the work of Maurice Blondel (1995) on 'living tradition'.

4 See, for example, Congregation for Catholic Education (1977) The Catholic School, London: CTS, where reference is made to 'the formation of the whole person' twelve times.

5 Pope Francis speaking at the Catholic-Inspired Non-Governmental Organisations (NGO) Forum, Rome December 2017 and December 2019.

6 Overall, it can be seen that the contribution of Gerald Grace's work in the period 20022016 can be interpreted as an early statement of Christian humanism. He did not use this term himself, but close analysis shows that he wrote in the spirit of Christian humanism before the Congregation for Catholic Education formally defined it in 2017.

\section{References}

Aquinas, St T. (2006). The Summa Theologica of St. Thomas Aquinas. Second and Revised Edition 1920. Literal translation by Fathers of the English Dominican Province (Kevin Knight), Online Edition.

Blondel, M. (1995). Complete Works, Paris: Universities of France Press.

Boland, V. (2007.) St Thomas Aquinas, London: Continuum.

Bowen, J. (1975). A History of Western Education: Volume III Civilisation in Europe, London: Methuen.

Bryk, A., V.E. Lee \& P.B. Holland (1993). Catholic Schools and the Common Good, Cambridge, MA: Harvard University Press.

Catholic Bishops Conference of England and Wales (2010). Meeting God in Friend and Stranger, London: CBCEW.

Congregation for Catholic Education (CCE) (2002). Consecrated Persons and Their Mission in Schools, London: CT.

Congregation for Catholic Education (CCE) (2017). Educating to Fraternal Humanism, London: CTS.

Dawson, C. (1961). The Crisis of Western Education, London: Sheed \& Ward.

Franchi, L. (2014) 'The Catholic School as a Courtyard of the Gentiles'. Journal of Catholic Education, Vol. 17, No. 3, Article 4, pp. 57-76.

Frankfurt, H. (1971). 'Freedom of Will and the Concept of a Person'. Journal of Philosophy, Vol. 67, No. 1, pp. 5-20.

Grace, G. (2002). Catholic Schools: Mission, Markets and Morality, London: Routledge Falmer. 
Grace, G. (2010). 'Renewing Spiritual Capital: An Urgent Priority for the Future of Catholic Education Internationally', International Studies in Catholic Education, Vol. 2, No. 2, pp. 117-128.

Grace, G. (2013). 'Catholic Social Teaching Should Permeate the Catholic Secondary School Curriculum: An Agenda for Reform', International Studies in Catholic Education, Vol. 5, No. 1, pp. 99-109.

Grace, G. (2016). Faith, Mission and Challenge in Catholic Education, London and New York: Routledge, World Library of Educationalists.

Grace, G. R. and O'Keefe, J. (2007). International Handbook of Catholic Education: Challenges for School Systems in the 21st Century, 2 Volumes, Dordrecht: Springer.

Himmelfarb, G. (1995). The De-Moralisation of Society, New York: Alfred A. Knopf.

Grassi, J. (1973). The Teacher in the Primitive Church and The Teacher Today, Santa Clara, CA: University of Santa Clara.

Lydon, J. (2011). The Contemporary Catholic Teacher: The Reappraisal of the Concept of Teaching as a Vocation in a Catholic Christian Context, Saarbrucken: Lambert Academic Publishing.

Lydon, J. (2012). 'Faith and the Catholic Teacher', The Pastoral Review, Vol. 8, No. 5, pp. 36-41.

McLaughlin, T.H. (1985). 'Religion, Upbringing and Liberal Values: A Rejoinder to Eamonn Callan', Journal of Philosophy of Education, Vol. 19, No. 1, pp. 119-127.

McLaughlin, T.H. (1999). 'Beyond the Reflective Teacher', Educational Philosophy o Theory, Vol. 31, No. 1, pp. 9-25.

Palmer, P.J. (1998). The Courage to Teach, San Francisco: Jossey-Bass.

Pope Benedict XVI (2007). Address of His Holiness Benedict XVI to the Participants in the first Meeting of University Lecturers, Rome: LEV.

Pope Paul VI (1967). Populorum Progressio, Encyclical Letter 'On the Development of Peoples' promulgated by Pope Paul VI on the Feast of Easter.

Rahner, K., S.J (1961). The Church as Sacraments, Freiburg: Herder.

Second Vatican Council (1965). Nostra Aetate/Declaration on the Relation of the Church to Non-Christian Religions, London: CTS.

Semmelroth, O., S.J. (1953). The Church as the Original Sacrament, Frankfurt: Main Knecht.

Schillebeeckx, E., O.P. (1964). Christ, the Sacrament of the Encounter with God, London: Sheed and Ward.

Sullivan, J. (2000). Catholic Schools in Contention, Leamington Spa: Veritas.

Sullivan, J. (2001). Catholic Education: Distinctive and Inclusive, Dordrecht: Kluwer Academic Publications.

Taylor, C. (1985) (ed.). Ethics, Ethnicity and Education, London: Kogan Page.

Whittle, S. (2018) (ed.). Religious Education in Catholic Schools, Oxford and Bern: Peter Lang.

Zimmermann, J. (2016). Re-Envisioning Christian Humanism: Education and the Restoration of Humanity, Oxford: Oxford University Press.

Zimmermann, J. (2012). Incarnational Humanism: A Philosophy of Culture for the Church in the World, London: IVP Academic. 